\title{
コナガ顆粒病ウイルス感染に伴う細胞の変化と NUCLEOCAPSID の出現部位
}

\author{
浅山哲・稲 垣育 雄
}

愛知県農業総合試験場

(1974 年 7 月 31 日受領)

\begin{abstract}
Cell Alternations Caused by the Infection with the Granulosis Virus in the Diamondback Moth, Plutella xylostella, and the Site of Appearance of Nucleocapsid. Tetsu Asayama and Ikuo InAgaki (Aichi-Ken Agricultural Research Center, Nagakute, Aichi 480-11) Jap. J. appl. Ent. Zool. 19 : 79 84 (1975)

Ultrastructural changes of the cell organellae in Plutella xylostella larva infected with the granulosis virus were observed by an electron microscope. Endoplasmic reticulum showed multilayered and whorl-shaped figures. Mitochondria changed into balloon-shaped structures with fragmented cristae. These abnormal structures disappeared into the cytoplasmic matrix at the advanced stage of the infection. During the conspicuous changes of cell organellae, 10 to 55 nucleocapsids protruded randomly in the cytoplasm of fat-body cells closely associated with rough endoplasmic reticulum, and regular stacking array of nucleocapsids were formed at the site of their appearance. Agglomerated glycogen granules and large clumps of lipid were seen in the infected cytoplasm.
\end{abstract}

緒 言

コナガ Plutella xylostella については，約 100 年前に イギリスで出版された成書にすでにアブラナ科野菜の重 要害虫としての記載が見られる (CuRTIs, 1883)。わが国 では佐々木 (1899) が本種をウンダイノアオムシテフと して記載しているが最近になるまでほとえど注目され ず，本種による野菜の被害が著しくなった約 10 年前か らようやく研究の対象昆虫となっている（山下，1963）。 著者らも本種による被害増加に注目し，票知県における その発生消長を調査したが（尾崎・浅山，1970)，この 時にコナガの顆粒病を発見した (AsAYAMA and OsAKI, 1970)。

顆粒病は 1926 年に PaILlOT によってPieris brassicae から発見されたのが研究の始まりといわれている(STEINHAUS，1949)。わが国では北島 (1938) が Pieris rapae crucivora の脂肪病について報告したのが最初のようであ る。このように比較的古くから知られているウイルス病 の1 種であるにもかかわらず，顆粒病ウイルス（granu1 コナガ顆粒病ウイルスに関する研究 第 1 報。 losis virus, GV と略す) の増殖部位に関する知見など， 多くのあいまいさがあると指摘されている (BIRD, 1959; HUGER, 1963)

著者らはコナガの顆粒病に関する研究の一環として, GV 感染幼虫脂肪体の電子顕微鏡観察を行い, 感染宿主 細胞の細胞学的変化ならびにウイルスの出現部位を明ら かにしたので，その概要を報告する。なお，本文に用い たウイルスに関する術語は, Goodwin (1968), Hughes (1972) の提唱を参考にして, 東 (1963) の定義に準拠し た。

本研究に対して, 数々のご助言を頂いた九州大学農学 部教授鮎沢啓夫博士に深謝の意を表する。

\section{材料 と方法}

供試顆粒病ウイルスはキャベツ畑に生息するコナガ幼 虫から常法により得たものに由来する (AsAYAMA and OsAKI，1970)。供試昆虫はコイトトロンを用いて飼育し たコナガ終令幼虫である。一部の幼虫にはあらかじめ微 量のトリトン $\mathrm{X}-100$ を添加した GV 顆粒の水浮遊液を キャベッ葉に叙布して与え, 初期病徵を示す GV 感染幼 
虫を準備した。別に刘照観察用に健康幼虫も準備し，そ れぞれを電子顕微鏡観察標本の材料とした。

材料の固定包埋から超薄切片を得るまでの手技は次の とおりである。まず $0.1 \mathrm{Ms}$-collidine 緩衝液と $3 \%$ オ ミウム酸水溶液を準借し, 別々に氷冷保存した。供試材 料の解剖直前に両液の等量混合液を調製し, 本液を幼虫 に注ぎながら解剖を行い脂肪体を摘出した。摘出脂肪体 の固定は本液にて 2 時間行い, 次の脱水処理はエ夕, ール・アセトン系列にて行った。この間に標本温度安徐 々に室温と同じまでに上げた。包埋はエポン 812 を用 い，超薄切片の作製には自家製ガラスナイフを装着した LKB 4800 型 Ultrotome を用いた。切片の染色は佐藤 (1968) の方法に準じて 鉛と䣷酸ウラニルによる二重染 色を行い，切片の観察には日本電子製 $\mathrm{T} 7$ 型電子顕微鏡
を使用した。

結

果

細胞小器管の形態変化 : コナガ幼虫の正常脂肪体細胞 ではミトコンドリアと小胞体が非常に 良く発達してい る。ミトコンドリアでは細脣い形態を示す像が多く,内 部に高密度のクリステ構造が認められる。またミトコン ドリア周辺には粗面小胞体が豊富に存在し，全休に電子 密度の高い像が得られた（第 1 図 a )。

GV 感染細胞では封入体形成部位(第 1 図矢印)の細胞 小器管がすでに消失しているために，正常細胞とは著し く異なり，透明な像が得られた（第 1 図 b , c )。ここに 至るまでの細胞小器管の形態変化を観察すると, そトコ ンドリアではまず輪郭が丸く膨潤状に变形し，また櫛状

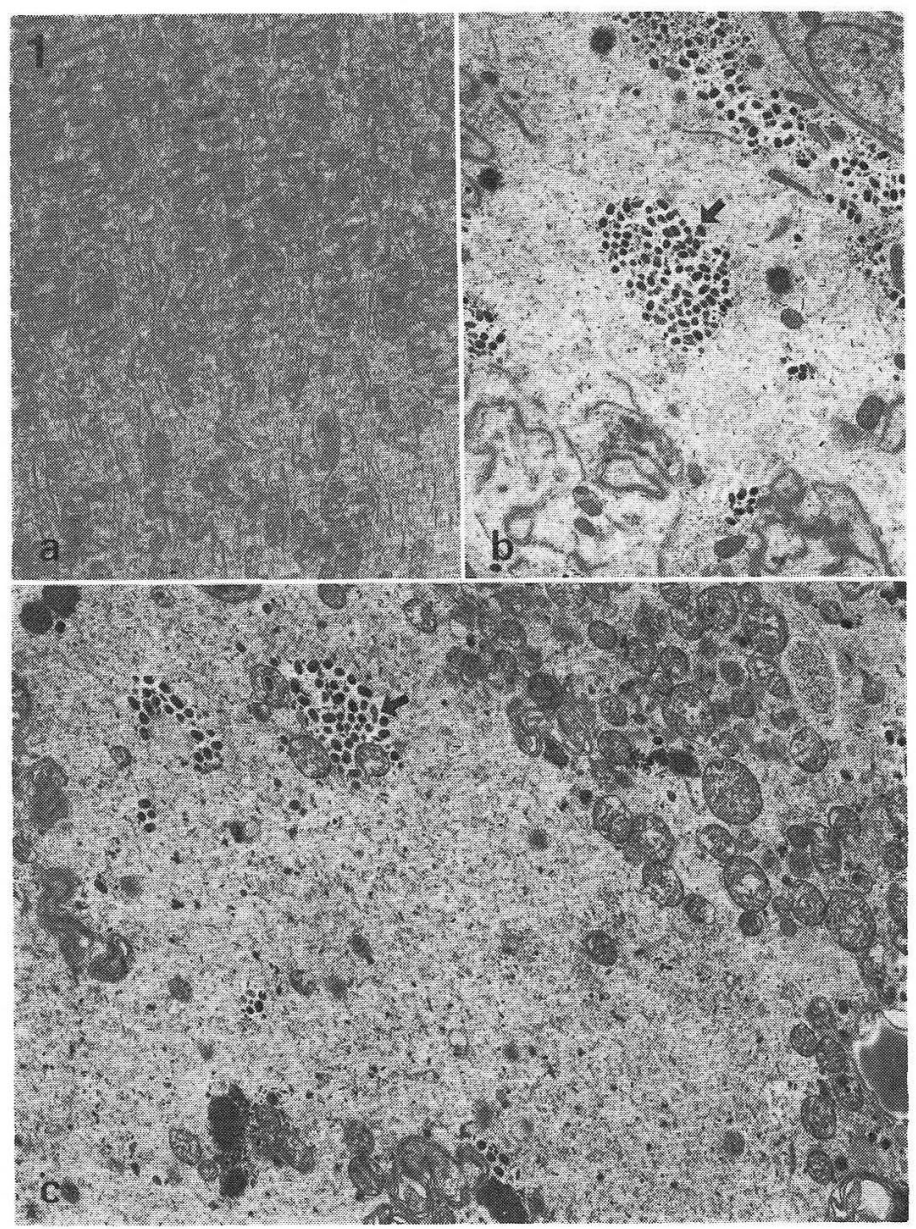

第1図 コナガ幼虫脂肪体細胞。 $\mathrm{a}$ : 正常細胞。 b , c : 顆粒病ウイルス感染細胞。 矢印は本交参照。 $\mathrm{a}: \times 4,700 . \mathrm{b}: \times 2,800 . \quad \mathrm{c}: \times 3,400)$ 


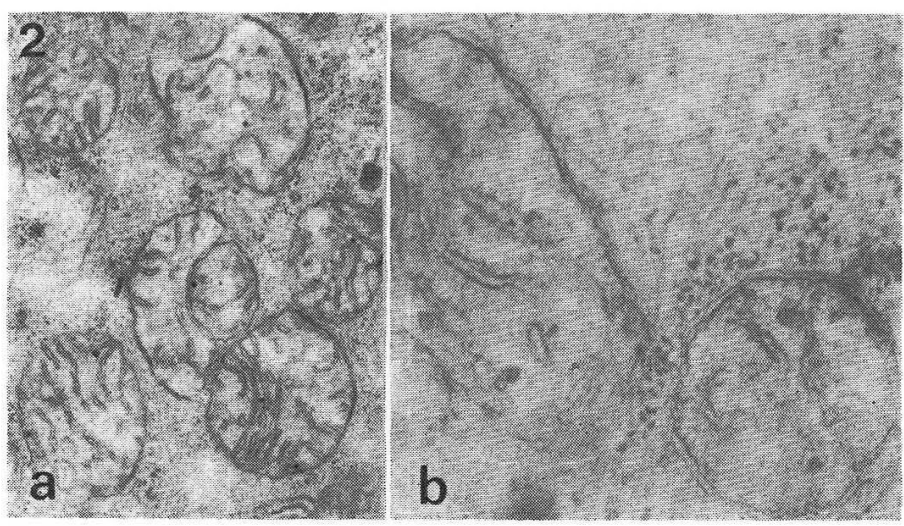

第2図 ミトコンドリアの変化。 $(\mathrm{a}: \times 15,500 . \quad \mathrm{b}: \times 31,000)$

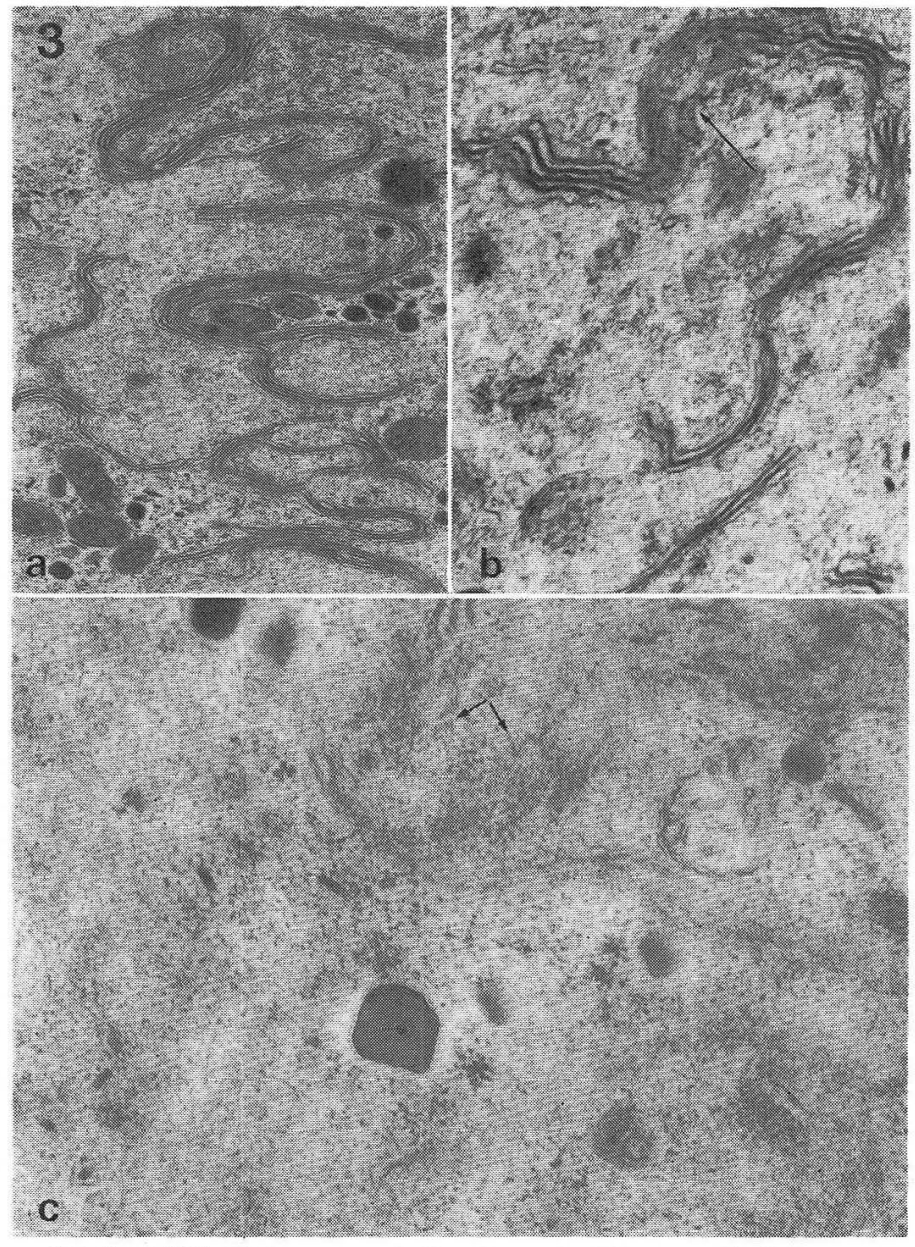

第 3 図 小胞体の変化。（a: $\times 7,800 . \mathrm{b}: \times 15,500 . \mathrm{c}: \times 31,000)$ 


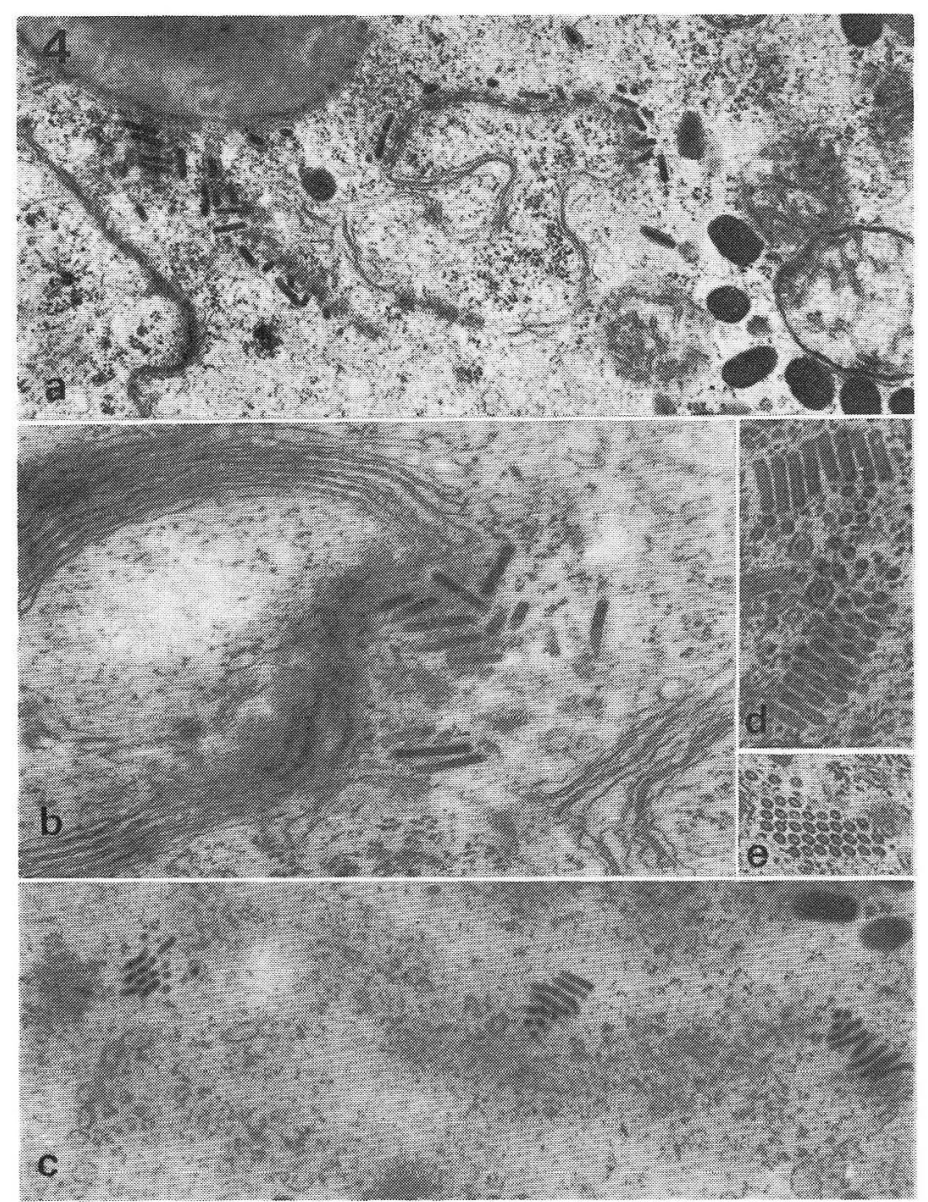

第4 図 nucleocapsid の出現。( a : $\times 15,500$. b : $\times 27,900$. c : $\times 15,500 . d, \quad \mathrm{~d}: \times 33,500)$

を呈する正常のクリステ構造は見られなくなった。クリ ステは強度に変形欠損し，基質の一部に偏在する状況孔 呈したが，最終的にはミトコンドリア内外膜と共に細胞 基質中に消失した（第 1 困 $\mathrm{c}$ ，第 2 図)。粗面小胞体は その数層が束状となり大きく波打つように湾曲し, 一部 は渦巻き状に変化するのが観察された（第 1 図b，第 3 园 a )。次に膜構造の崩壊が始まり（第 3 図 b 矢印）, 膜 を構成していたと思われる好染性物質が雲絮状に拡散 し，最終的にはミトコンドリアと同様に細胞基質中に消 失した（第3図 $\mathrm{c}$ 矢印）。その結果, GV 感染細胞では 既存の細胞小器管像が著しく減少した。

NuCLEOCAPSID の出現 : nucleocapsid 残存する粗 面小胞体膜に沿うようにして出現した。本像は初め小胞 体膜の片側に 1 本ずつばらばらに突出すようにして形成 され(第 4 図a), 本像の発達に伴い隣接する小胞体膜
構造はさらに崩壊した（第4 図b)。このようにして山 現した nucleocapsid け, 次に 10〜55 本程度集合し, その横断面では直線状積層配列を示す nucleocapsid の 塊が形成された（第 4 図 d, e ）。前述の細胞小器管の消 失時期と集塊状 nucleocapsid の形成時期とは一致した (第4 図 c)。また nucleocapsid はその芯部が中空状に

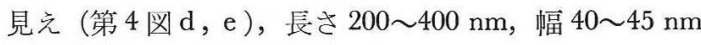
の長程状形態を有するようであった。別に報告する被 膜，封入体蛋白，管状構造体等の GV の成熟に関係する 各種の像は，これらの集塊状 nucleocapsid 付近の細胞 基質より出現した。

グリコーゲン顆粒およびリピッド : 正常の脂肪体細胞 に怙けるグリコーゲン顆粒およびリピッド像はわずかに 散在的に認められる程度であるが，GV 感染細胞ではこ れらの巨大な凝集像がしばしば認められた（第５図）。 


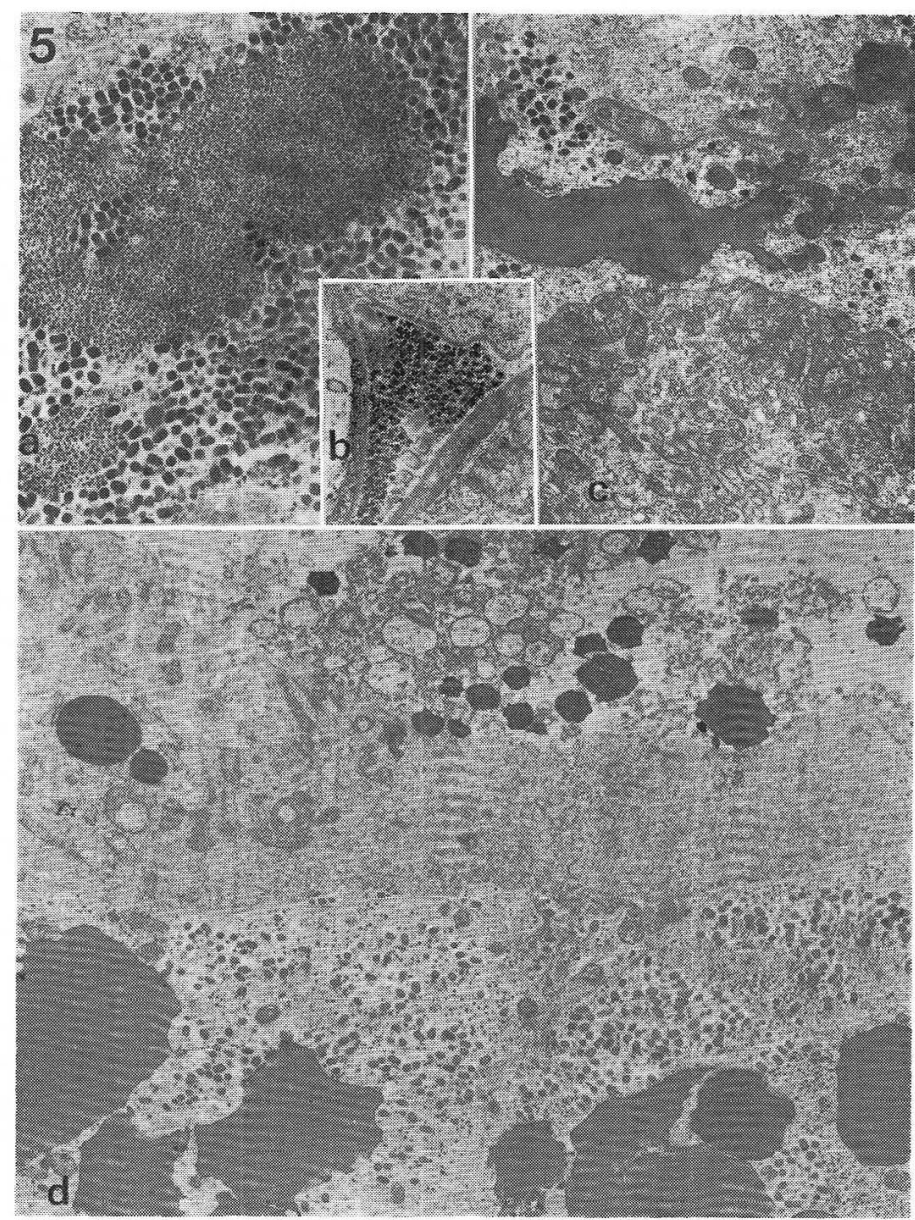

第 5 図 グリコーゲン顆粒枋よびリピッド。( a : × $\times 3,200 . b: \times 7,100 . \quad \mathrm{c}, \mathrm{d}: \times 2,800)$

なたグリコーゲン顆粒では GV 封入体と共に細胞間隙中 に流出している像も認められた（第 5 眓b）。隣接する 2 個の細胞に㧍けるリピッドの存在状況を観察すると， 第 5 図 $\mathrm{c}$ 上半部の細胞には封入体とリピッドの両像が認 められるが下半部の細胞にはいずれも認められない。第 5 図 d では 2 個の細胞ともリピッド像が認められるが, 封入体形成の見られる細胞に多くのリピッド像が存在 し，融合寸前と思われる像も認められた。

$$
\text { 考察 }
$$

GV 感染コナガにおける粗面小胞体は, 多様な形態变 化定しながらも nucleocapsid の突出時にはまだ存在 している。このことは nucleocapsid の形成に要する物 質連絡が核その他の細胞小器管との間に行われているの を示唆しているようである。また GV 感染 Plodia inter- punctella では nucleocapsid が湾曲状小胞体膜に沿うよ らにして出現している像が観察されており (ARNOTT and SмIтH, 1968), GV 感染 Cadra cautella では nucleocapsid が cytomembrane に接し，整列状に形成されている (Hunter and Hoffmann, 1970)。著者らにはこの cytomembrane は小胞体膜のように見うけられるが， cytomembrane が小胞体膜に相当する器管であるとすれば, Plodia interpunctella 抢よび Cadra cautella の GV もコ ナガ GV と同様に，nucleocapsid は宿主細胞の粗面小 細体膜に近接する部位に出現している可能性も考えられ る。

ArnotT and Sмiтн (1968) は GV 感染 Plodia interpunctella において, 無被膜 nucleocapsid 形成部位付近に おけるミトコンドリアの蓄積像を観察し，渡部・今西 (1972) は GV 感染 Adoxophyes fasciata において, ミ 
トコンドリア，リピッドおよびグリコーゲン顆粒の散在 を観察している。GV 感染コナガではこれらの報告とは 異なり，ミトコンドリアは消失し，グリコーゲン顆粒は 凝集している。さらにりピッドは正常細胞に見られる場 合よりはるかに巨大であり, GV 感染に伴う宿主細胞の 異常代謝が想像される。

$$
\text { 摘要 }
$$

電子顕微鏡を使用して，顆粒病ウイルス感染コナガに おける細胞小器管微細胞構造の変化を観察した。

ウイルス感染脂肪体細胞の細胞小器管には著しい变化 が認められた。粗面小胞体は多層渦巻き状に变形し, ミ トコンドリアはクリステの損傷を伴い丸く膨潤した。感 染が進行するとこれらの異常構造体は細胞基質中に消失 した。無被膜 nucleocapsid は粗面小胞体に近接し, 細胞 質に出現した。最初ばらばらに突出した各 nucleocapsid は出現部位にて 10〜55 本程度集合し, 直線状皘層配列 を示す集塊を形成した。感染細胞質には凝集状グリコー ゲン顆粒と巨大なりピット塊が認められた。

\section{引 用 文 献}

Arnott, H. J. and K. M. SMith (1968) An ultrastructural study of the development of a granulosis virus in the cells of the moth Plodia interpunctella $(\mathrm{Hbn})$. J. Ultrastruct. Res. 21 : 251 268.

Asayama, T. and N, Osaki (1970) A granulosis of the diamondback moth, Plutella xylostella. J. Invert. Path. 15 : 284 286.

BIRD, F. T. (1959) Polyhedrosis and granulosis viruses causing single and double infections in the spruce budworm, Choristoneura fumiferana Clemens. J.
Insect Path. $1:$ : 406 430.

CuRTIS, J. (1883) Farm Insect: Insects Injurious to the Field Crops. John van voost., London, 528 pp.

Goodwin, R. H. (1968) Use of the term "virus inclusion body" and vernacular virus names. J. Invert. Path. 12 : 479 480.

東 昇 (1964) ウイルスの電子顕微鏡学的研究. 医学生物学用 電子顕微鏡学 (東昇編), 文光堂, 東京: 352 400.

Huger, A. (1963) Granulosis of insects. In "Insect pathology" (E. A. Steinhaus ed), Academic Press, New York : 531 $\sim 575$.

Hughes, K. M. (1972) Fine structure and development of two polyhedrosis viruses. J. Invert. Path. 19 : 198 207.

Hunter, D. K. and D. F. Hoffmann(1970) A granulosis virus of the almond moth, Cadra cautella. J. Invert. Path. 16: 400 407.

北島銊雄 (1938) モンシロテフ (Pieris rapae crucivora BoISDUVAL) 幼虫の脂肪病に就て。鹿児島高農学報 13 : 111 116

尾崎典光・浅山 哲 (1970) 愛知県におけるコナガの生活史. 関 西病虫研会報 $12: 30 \sim 34$.

佐藤泰山（1968）超薄切片用鉛染色法の一改良法. 電顕学会誌 $17: 158 \sim 159$.

Steinhaus, E. A. (1949) Priciples of Insect Pathology, McGraw-Hill., New York, 757 pp.

佐々木忠二郎 (1899) 日本農作物害虫篇, 敬業社, 東京, $439 \mathrm{pp}$ 山下善平 (1963) コナガの発生消長について.今月の農薬 7(11) $50 \sim 54$.

渡部 化·今西健一 (1972) 顆粒病ウイルスに感染したチャノコ カクモンハマキ脂肪体の電子顕微鏡観察. 応動昆 16:193 $\sim 201$. 